Social Sciences on Contemporary Turkey

19 | 2014

Heritage Production in Turkey. Actors, Issues, and

Scales - Part I

\title{
Insurmountable Tension? On the Relation of World Heritage and Rapid Urban Transformation in Istanbul
}

\section{Vivienne Marquart}

\section{OpenEdition}

\section{Journals}

Electronic version

URL: http://journals.openedition.org/ejts/5044

DOI: $10.4000 /$ ejts.5044

ISSN: $1773-0546$

Publisher

EJTS

Electronic reference

Vivienne Marquart, «Insurmountable Tension? On the Relation of World Heritage and Rapid Urban Transformation in Istanbul », European Journal of Turkish Studies [Online], 19 | 2014, Online since 11 December 2014, connection on 16 February 2020. URL : http://journals.openedition.org/ejts/5044 DOI : $10.4000 /$ ejts.5044

This text was automatically generated on 16 February 2020

(c) Some rights reserved / Creative Commons license 


\title{
Insurmountable Tension? On the Relation of World Heritage and Rapid Urban Transformation in Istanbul
}

\author{
Vivienne Marquart
}

I would like to thank the editorial board and two anonymous reviewers for their valuable comments on earlier drafts of this article

\section{Introduction}

1 The UNESCO World Heritage (WH) label is nowadays used by different actors to promote tourist destinations and to highlight the unique character of single sites. In recent years, UNESCO (i.e. the World Heritage Committee) has become a reference point in statements made by local activists and newspapers in Istanbul criticizing current developments at WH sites. This, however, does not indicate the growing influence of UNESCO at the local level, and associations with the famous list are often misguided (Askew 2010).

2 In this article, I would like to untangle the different actors involved in the heritage management in Turkey with a particular focus on Istanbul. Large and extravagant urban transformation projects have been realized under the ruling Justice and Development Party (AKP), many of them in Istanbul (Pérouse 2013, Y1lmaz 2012, Kuyucu and Ünsal 2010, Kurtuluş 2009, şen 2009). Current projects in Istanbul include the construction of a third Bosporus Bridge, the building of a canal parallel to the Bosporus, and the reconstruction of historic neighbourhoods. Recently a metro bridge over the Golden Horn and a railway tunnel under the Bosporus were opened. These transformation projects often negatively affect the city's built cultural heritage, including protected WH areas. 
3 In this article I argue that the current changes taking place in historic neighbourhoods are part of a broader political agenda, which is not opposed, but supported by UNESCO's international program for the protection of cultural heritage. The establishment of a formally elaborated framework of heritage management has gained international approval. At the same time, the number of newly established institutions and regulations has created a certain degree of ambiguity at the local level, which has allowed urban transformation to take place even in protected World Heritage areas. Turkey's heritage management system, does not oppose urban transformation, but rather it enables the realization of development projects in historic neighbourhoods.

4 In a first part, I will describe the different institutions and legal regulations that are involved in the administration of $\mathrm{WH}$ on the global, national, and local level in order to trace the complex management system of WH sites in Turkey. The interaction between different actors is often fractured and incomplete, with communication problems and unclear responsibilities (Somuncu and Turgut 2010). Instead of viewing this as a structural problem, I argue that certain inconsistencies are intended by central and local authorities in order to provide a flexible frame for the implementation of transformation projects in historical neighbourhoods. The establishment of a multilayered management system not only pleases international organizations and investors, but also offers the opportunity to include local actors in a centrally controlled institutional framework.

5 In the second section, the Historical Areas of Istanbul, inscribed on the WH List as one of the first sites in Turkey, will be the main focus. Many of the recent urban transformation projects are situated in, or are close to the historic neighbourhoods. While the UNESCO World Heritage Committee (WHC) did not implement any of the proclaimed sanctions against the destruction of protected areas, the revival of heritage serves as an important factor for investments and tourism in these areas.

6 In the last part, I will illustrate how urban transformation and historic preservation has been combined in a centralized management system in Istanbul. The widely accepted (re)production of heritage, and the relative powerlessness of UNESCO's WHC on a local level, supports a heritage management system in favour of huge transformation projects.

7 The material presented in this article is based on 15 months ethnographic fieldwork conducted in Istanbul between July 2012 and October 2013 for my dissertation. ${ }^{1}$ During this period I intensively followed the reconstruction of Istanbul's historic neighbourhoods in Ayvansaray, Süleymaniye, Zeyrek, and Tarlabaşı, as well as the construction of the metro bridge over the Golden Horn and in Taksim Square. I supplemented my own observations with interviews and two smaller surveys. My interview partners were residents and workers in the historic neighbourhoods, volunteers and activists from Istanbul's civil platforms, and academics, architects, and urban planners. I also talked to members of ICOMOS (International Council on Monuments and Sites) Turkey, and the Turkish National Commission of UNESCO, and in addition to employees from different municipalities, national institutions, and the Ministry of Culture and Tourism. To ensure their anonymity, I have changed the names of all the individuals in this article. 


\section{Heritage on the Ground: The Management of Cultural Heritage Sites in Turkey}

8 The WH arena, widely known only under the label of UNESCO, is in fact a complex system of institutions consisting of the WHC, the World Heritage Centre (UNESCO headquarters in Paris), and the advisory bodies ICOMOS (International Council on Monuments and Sites), ICCROM (International Centre for the Study of the Preservation and Restoration of Cultural Property), and IUCN (International Union for Conservation of Nature). The decision-making body of the WHC is formed of the representatives from 21 of the 191 biannually elected States Parties. ${ }^{2}$ Hence, decisions at different heritage sites are not primarily influenced by UNESCO as an international entity, but by the complex composition of several States Parties in the WHC and experts within the advisory bodies.

9 Turkey became a State Party to the 1972 "UNESCO Convention Concerning the Protection of the World Cultural and Natural Heritage" in $1982 .{ }^{3}$ In the same year, the "Legislation for the Conservation of Cultural and Natural Heritage" [Kültür ve Tabiat Varlklar Koruma Kanunu, Law No. 2683] was adopted, which was followed by the first inscriptions on the WH List in $1985 .{ }^{4}$ However, to date, there is no specific legislation protecting WH areas. The Turkish National Commission for UNESCO in Ankara is a semi-governmental organization that is intended to act like as a broker between the government and the UNESCO World Heritage Centre. ICOMOS Turkey, and the national committee of ICOMOS, evaluates and reports on the conservation of Turkey's WH sites. However, both organizations' influence has been marginalized by strong state control.

With the introduction of a new municipality system for the biggest cities in 1984, the responsibilities of Turkish cities were divided between metropolitan municipalities and district municipalities. ${ }^{5}$ The Turkish political system is divided into three tiers, the national government (with centrally appointed governors in 81 provinces), and metropolitan and district municipalities. While district municipalities should be responsible for the sites and problems within their own districts, Istanbul Metropolitan Municipality [İstanbul Büyükşehir Belediyesi, IMM] handles problems concerning the entire city. The national government is responsible for WH sites and all projects taking place within protected areas (Günay and Dökmeci 2012). In fact, the vague division of responsibilities often causes confusion and contradictions, as a skyscraper project in Zeytinburnu neighbourhood in Istanbul demonstrated in 2011 when the unclear demarcation of specially protected areas caused disagreement between the Ministry of Culture and Tourism [Kültürr ve Turizm Bakanlığl], the Superior Conservation Council for Cultural and Natural Assets [Kültür ve Tabiat Varliklarını Koruma Yüksek Kurulu or Anitlar Yüksek Kurulu], the IMM, and Zeytinburnu municipality. Officials from Ankara claimed that the planned project infringed on the protected WH areas, and the Ministry of Culture and Tourism (MCT) determined that the building project had a negative impact on the silhouette of the historic areas. However, referring to a permit issued by IMM and Zeytinburnu municipality, the construction of the building continued (Hülagü 2011).

11 In general, the MCT has extraordinary decision-making power in Turkey's cultural affairs. ${ }^{6}$ However, most of the institutions involved in the management of heritage are much older, with origins in the late $19^{\text {th }}$ century Ottoman period (şahin Güçhan and 
Kurul 2009). Only after the 1980 s were some modifications made to the legal regulations concerning the preservation and conservation of cultural (and natural) heritage. ${ }^{7}$

The MCT heads different directorates concerned with heritage management: The General Directorate of Fine Arts, the Central Directorate of Revolving Funds, the General Directorate of Cultural Heritage and Museums, and the 12 directorates of survey and monuments. The General Directorate of Cultural Heritage and Museums administers the 99 Museum Directorates [Müze Müdürlükleri], eight of which are located in Istanbul. The aforementioned Superior Conservation Council is also under its administration. It supervises the Regional Conservation Councils [Kültür Varlklarını Koruma Bölge Kurulu Müdürlükleri], of which six of the 32 are based in Istanbul alone. Additionally, there are two special councils for renewal in Istanbul, but not for any other region in Turkey.

The Museum Directorates have no autonomy, but rather serve as geographical units for the administration of museums. The Regional Conservation Councils approve conservation and development interventions at listed sites and they can list cultural heritage, albeit only under the supervision of the Superior Conservation Council. This does not mean that the MCT with its directorates is the most active conservation institution in Turkey. In fact, the General Directorate of Pious Foundations [Vakıflar Genel Müdürlüğ̈̈], established in 1920 and directly bound to the Prime Ministry, administers cultural heritage constructed by Seljuk/Ottoman pious foundations. Currently, it supervises around 4500 foundations with their historical buildings and monuments. Its only link to institutions under the MCT is the evaluation of conservation plans by the Regional Conservation Councils. ${ }^{8}$

The administration of museums is also not exclusively regulated by the MCT. Twelve museums, among them the highly frequented Anitkabir Museum in Ankara, are under the control of the Ministry of Defence. In contrast, national palaces, such as the Dolmabahçe Palace in Istanbul, and parliamentary buildings are managed by the Directorate of National Palaces [Milli Saraylar Daire Başkanliğl], which is linked to the Grand National Assembly. 


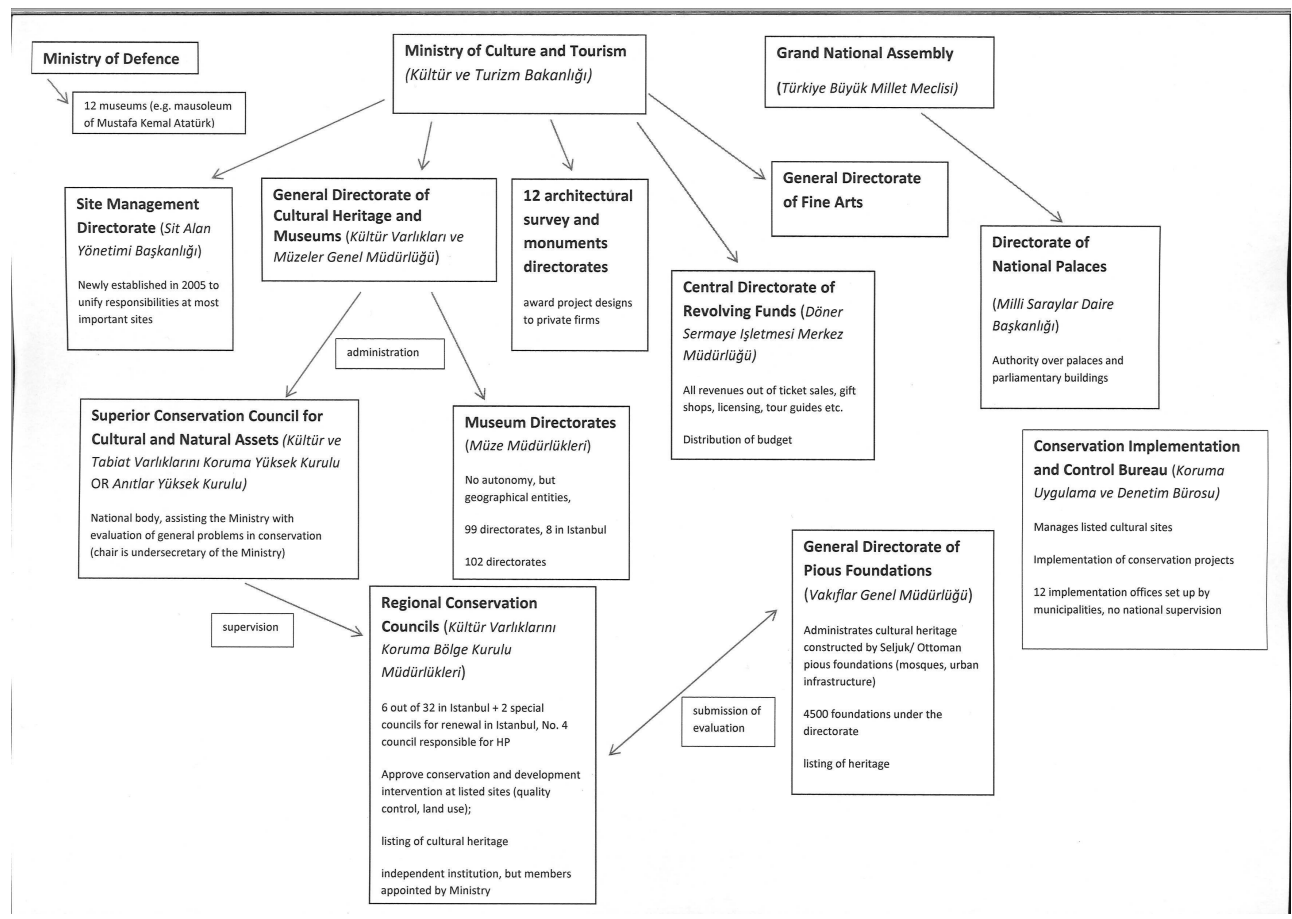

Simplified presentation of the most important institution for the management of heritage in Turkey (national level)

Marquart, 2014

Together with the City Planning Directorate at the metropolitan level and the Directorates of Housing and Urban Development at the municipality level, the Ministry of Environment and Urban Planning [Çevre ve şehircilik Bakanlı̆̆l] is also involved in the conservation of built heritage. Since 2012 the Ministry has extended powers for constructions in areas declared as sites under the risk of natural disaster.

The IMM and district municipalities are responsible for the realization of different conservation and renewal projects. With new legal regulations which will be later discussed in greater detail, the municipalities additionally gained extraordinary powers in urban transformation and development projects in historic areas.

Since 2005, new allocations of additional funds for the conservation of cultural heritage enabled the Special Provincial Administration [ill Özel İdaresi, SPA] to support municipalities in the realization of conservation and restoration projects, making it another important institution in the preservation of heritage areas. However, the implementation of Law No. 6360, adopted in October 2012, abolished the SPAs in all provinces where metropolitan municipalities had been established (Deniz and Çalışkan 2014). From then on, the newly established Centres for Investment Monitoring and Coordination [Yatırm İzleme ve Koordinasyon Merkezleri], bound to the provincial governor, were instituted to manage the funds allocated by the national government. Other responsibilities of the SPAs were also to be taken over by the metropolitan municipalities (Çektir 2012).

The heritage management system is thus changing permanently and continuously. Especially in the last decade responsibilities have shifted constantly and new institutions emerged regularly. As a result of this scattered management system the WHC asked for changes to be made to the heritage management system, especially with regard to Istanbul's site management (e.g. UNESCO 2006a). This request helps to 
explain the recent introduction -also in Istanbul- of local Conservation Implementation and Control Bureaus [Koruma Uygulama ve Denetim Bürosu] and Site Management Directorates [Sit Alan Yönetimi Başkanlkları] for the coordination of responsibilities at the most important cultural sites. So far, these institutions have been inadequately established and insufficiently funded. What emerges, however, is the influence of UNESCO's heritage management standards on the organization of heritage preservation at the national level. International principles are important features that have been adopted by the Turkish government and incorporated into the national heritage management system.

19 In a detailed report, Somuncu and Turgut (2010) describe both the national and local failures of Turkey's heritage preservation. In their opinion it is not only the division of responsibilities between several governmental and non-governmental institutions and different stakeholders that is responsible for the lack of coordination. To date, no WH sites visitors plan exists, and financial resources are still insufficiently distributed. Very often, local people were unaware of the historical sites or do had even remained uninformed about the inclusion of their area of residence in UNESCO's WH program. In fact, what has been interpreted by these authors as a defect in heritage management can also be viewed from a strategic perspective, as a tool for the centralization of control over the processes of heritage production and the transformation of designated heritage areas. Decentralization in Turkey has not resulted in less state control, as one may have assumed (Bayraktar and Massicard 2012; Bonini Baraldi et al. 2014). On the contrary, it has enabled the government to assert more control over heritage management and urban transformation through the establishment of centrally administered institutions in local contexts. ${ }^{9}$ Additionally, the ruling AKP's dominance at both the local and national level has produced local politics congruent with the national agenda. In heritage management UNESCO's international standards and terminologies are formally adopted to support the national governments agenda (Black 2001). This, however, does not change the fragmented nature of Turkish heritage management with many different institutions involved in heritage preservation. ${ }^{10}$

The loopholes in this historically grown, fragmented heritage management system provide fruitful grounds for the promotion of politically favoured urban transformation projects over heritage preservation. The centralized fragmentation of responsibilities, obscured by decentralization, gave new powers to local institutions, facilitating the rapid realization of large transformation projects. These developments have become especially visible in Istanbul, where large parts of the city are designated urban renewal sites and where newly established institutions, such as the Site Management Directorate or KUDEB [Koruma Uygulama Denetim Müdürlügü], have become additional players in the multi-faceted heritage management system. To elaborate on the specific case of Istanbul, I will describe the inscribed WH areas in more detail, before presenting legal changes and subsequent reactions of various stakeholders that occurred within this context.

\section{Legal Changes and World Heritage in Istanbul}

21 Currently a city with a population of approximately 14 million people, Istanbul has never been a city of one-sided development. The city's cultural heritage includes assets from these different periods, which is also mirrored in the selection of its WH areas. 


\section{The Historical Areas of Istanbul}

The Historical Areas of Istanbul were inscribed on the WH List in 1985 as one of the first sites in Turkey, only two years after the national government's ratification of UNESCO's "Convention Concerning the Protection of the World Cultural and Natural Heritage". The Historical Areas of Istanbul, listed as one site, consists of four protection zones within the Historic Peninsula: the Theodosian land walls, the Zeyrek Mosque and associated conservation area, the Süleymaniye Mosque and associated conservation area, and the Archaeological Park. ${ }^{11}$

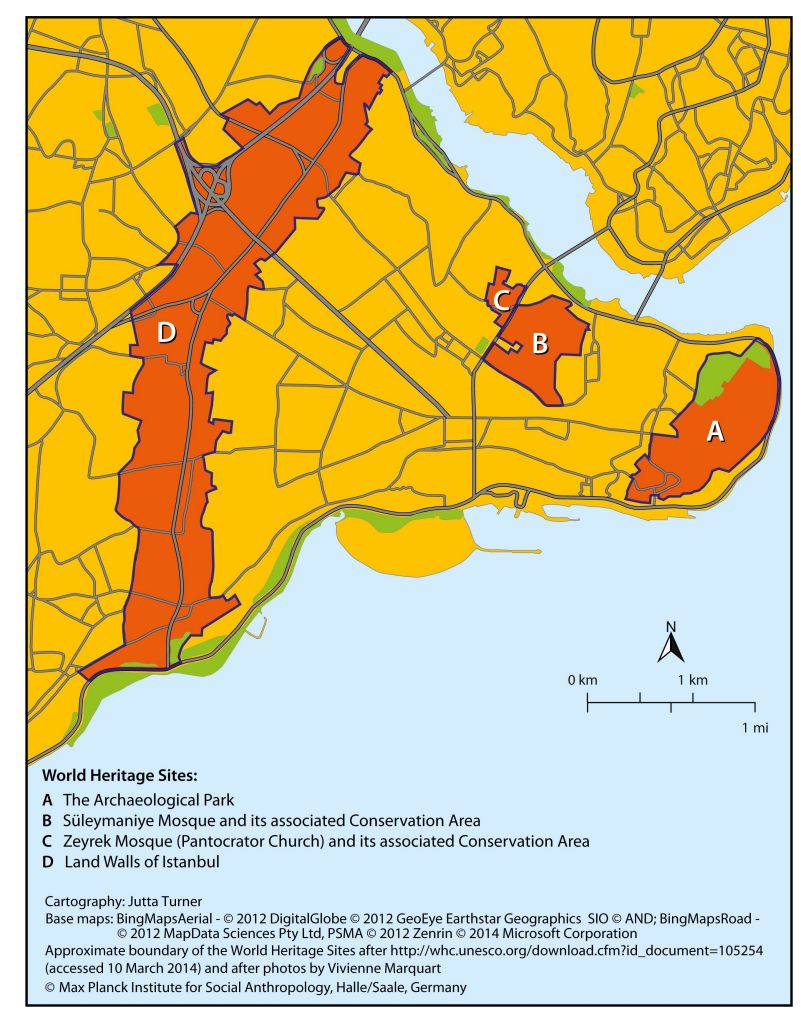

APPROXIMATE BOUNDARY OF THE WORLD HERITAgE SITES

SEE PICTURE

The Historical Areas of Istanbul were included on the WH List for their architectural masterpieces and the incomparable skyline originating from Byzantine and Ottoman times. ${ }^{12}$ The site contains unique monuments as well as residential architecture from different periods. While the Archaeological Park is the main tourist attraction with monuments like the Hagia Sophia and Topkapı Palace, Süleymaniye and Zeyrek are famous mostly for their mosque complexes [külliye] and the vernacular architecture. The area along the land walls contains important monuments from Byzantine times as well as vernacular settlements.

\section{Decentralization and Legal Changes since the 1980s}

24 As described in other contexts by Berliner (2012) and Joy (2012), heritage is often not connected to preservation but more to change. The past is negotiated in the present (Herzfeld 1991, 2006) and is used for the promotion of tourism, city branding, as well as 
for attracting investment in urban transformation projects (Labadi and Long 2010). Hence, the recognition of a heritage site often triggers development in historic areas. ${ }^{13}$

In Istanbul too, the inscription of $\mathrm{WH}$ areas coincided with a period of extensive infrastructural and urban transformation. In the 1980s, the Turkish government concentrated on economic liberalization and political decentralization (see also Kocabaş 2006). Likewise, new legal provisions for deregulation were introduced to stimulate the market economy. In accordance with these institutions, the "Law for the Encouragement of Tourism" [Turizmi Teşvik Kanunu, Law No. 2634], approved in 1982, became one of the most important planning tools to justify vast urban transformation projects. Demolition of vernacular houses and displacement of its residents took place especially in the historic neighbourhoods of Istanbul's Peninsula (Bezmez 2008).

With the shift from an industrial to a service economy under the ruling AKP after 2002, the concept of urban transformation [kentsel dönüşüm] and the implementation of big infrastructural projects became a major point on the political agenda. In recent years, the national government established an elaborated legal framework that is the basis of recent urban transformation projects in many of the historic neighbourhoods in Istanbul. After the 1999 earthquake and its devastating impacts, urban transformation was presented by the central government as an obligation for the creation of a safe and clean urban environment. This went along with the legal strengthening of the Housing Development Administration [Toplu Konut İdaresi Başkanliğı, TOKİ] and the establishment of a legal framework that supports these interventions (Yllmaz 2012).

In 2005, the Law on the "Preservation by Renovation and Utilization through Revitalizing Deteriorated Immovable Historical and Cultural Properties" [Yipranan Tarihi ve Kültürel Tașınmaz Varlıkların Yenilenerek Korunması ve Yașatılarak Kullanilması Hakkınada Kanun, Law No. 5366] organized the principles and methods for the reconstruction and restoration of cultural and natural properties. In fact, the law allows municipalities to take neighbourhoods classified as "deteriorated areas" out of the normal planning system to make way for the rapid transformation in these areas. Thus, UNESCO also recognized the law's risk of favouring development over conservation (UNESCO 2006b). Istanbul activist groups and academics criticized the law for its exclusion of local residents, violation of property rights, and neglect of the social dimension of urban transformation projects (see Dinçer et al. 2008; Kuyucu and Ünsal 2010). Despite these critiques, Law No. 5366 has constituted the basis of recent urban transformation projects in historic neighbourhoods in Istanbul.

Urban transformation, accompanied by the demolition of inner-city, low income neighbourhoods, is often justified by the threat of natural disaster (Saraçoğlu and Demirtaş-Milz 2014). Therefore, in 2012 the "Law on the Transformation of Areas under Disaster Risk” [Afet Riski Altındaki Alanların Dönüştürülmesi Hakkında Kanun, Law No. 6306] was adopted, establishing the principles and procedures for the transformation of at risk areas. As Istanbul lies in an earthquake-prone area, and consequently is a city considered to be at enormous risk of natural disasters, the law provides a powerful tool for the Ministry of Environment and Urban Planning the justification of transformation projects in almost every neighbourhood within the city.

New legal regulations gave greater responsibilities to municipalities, which have become increasingly important in the realization of transformation projects in historic neighbourhoods. However, as discussed in the previous section, decentralization in this 
respect did not result in less state control, but rather enabled the local government to more rapidly implement the national urban transformation agenda.

\section{Reactions of Different Stakeholders}

All these legal changes have provoked a wide range of responses from different local stakeholders. The given examples in this article do not reflect the extensive variety of reactions, but instead provide an overview on dominant positions with regard to the subsequently presented case studies.

Activist groups such as Bizim Avrupa ${ }^{14}$ have repeatedly expressed concern about these new legal regulations and the strong focus on urban transformation as opposed to the preservation of historic neighbourhoods. The WHC also marked the developments occurring in these areas as inappropriate to the protection of WH areas (e.g. UNESCO 2009). This is the reason why, since 2003 the WHC repeatedly threatened to include the Historic Areas of Istanbul on the List of WH in Danger (UNESCO 2003). In its latest session, however, the WHC refrained from considering the inscription on the List of WH in Danger. This could be interpreted as an appreciation of current efforts, which have pointed towards a positive change in the preservation of heritage. As the State Party prepares the reports for the WHC session, however, it is difficult for the WHC to accurately evaluate the actual improvements made at a local level. The UNESCO World Heritage Centre and ICOMOS Joint Reactive Monitoring Missions, arranged for Istanbul in 2006, 2008, 2009 and 2012 respectively, are organized only when a deletion from the List or an inscription of the property on the List of WH in Danger has already been discussed..$^{15}$ Therefore, the missions, comprising one representative from the UNESCO World Heritage Centre and one from ICOMOS International, aim to evaluate the general conditions of the property but are unable to consider site-specific implementations.

Local stakeholders seldom participate actively in the debate by sending information and / or making a complaint to the World Heritage Centre, as people are either inadequately informed about these options or assume that regardless their concerns will go unheard. Onur, who is in his thirties and calls himself an urban activist, expressed his frustration stating:

UNESCO ... now people are talking about it. But they don't understand that UNESCO won't help with anything. Even if you write to them, telling what is happening here, they will not listen. They are working with the government, not with us. ${ }^{16}$

His latter assertion is rightly assumed as UNESCO is a transnational organization composed of its States Parties it is, therefore, directly linked to national governments. However, even if the WHC had the tools to better evaluate the status of specific sites, and even if local stakeholders were more actively engaged in reporting to the World Heritage Centre, UNESCO's relative powerlessness on the ground would remain unchanged. The only way to apply pressure to the States Parties is the listing of a site on the List of WH in Danger or its definite removal from the WH List. The small number of sites inscribed on the List of WH in Danger, and the removal so far of only two sites from the WH List, however, shows that these tools are rarely used. ${ }^{17}$ Therefore, UNESCO WH status, often presented as a safeguard for heritage, proves insufficient for the protection of cultural heritage sites.

Three major arguments have been presented so far: Firstly, UNESCO is no guarantor for safeguarding heritage, having limited powers to influence the preservation of specific 
WH sites. However, as an international organization it sets the standards for heritage management, the standards of which are also reflected in recent changes to Turkey's management system. Whether or not this is an improvement for the preservation of heritage will be discussed in the next part of the article. Secondly, heritage -in Turkey as elsewhere- is used to attract tourism and investment. This means that sites, labelled as cultural heritage, are at the same time exposed to transformation. As the case of the historical neighbourhoods in Istanbul attest, heritage is not static but always connected with change. Thirdly, as I argue, Turkish heritage management combines these two aspects -the international framework, connected to decentralization, and the inherent transformation of heritage- to enforce its urban transformation policy. The "centralized fragmentation" of heritage management creates ambiguity between different stakeholders. This ambiguity ensures centralized control over the urban transformation of heritage areas without conflicting with UNESCO standards.

In the last section, I will discuss how urban development and historic preservation are combined in Istanbul's historic neighbourhoods.

\section{III: Insurmountable Tension?}

Several authors have discussed the focus on Ottoman heritage for the promotion of a new Turkish-Muslim identity (Bartu 2001; Öncü 2007; Eldem 2012), and have referred to inventions like the annual Tulip Festival ${ }^{18}$ in corroboration of this reading (Öncü 2010). However, the national government and the IMM have recently also spent large funds on the reconstruction and preservation of Byzantine heritage, especially in preparation for the 2010 European of Capitals of Culture campaign. The much older Byzantine remains and monuments dating back to the city's Christian past became important markers for the tourist industry (Fuhrmann 2013: 261).

Zeyrek Mosque, the former Church of Pantokrator and the second largest remaining religious monument of Byzantine origin, underwent essential restoration works in the past decade after the whole neighbourhood had been left in a state of decay for many years. A restoration project for Zeyrek Mosque had already been started in 1995 . However, it was held up for several years by official authorities and was ultimately halted in 2005 when the General Directorate of Pious Foundations assumed overall responsibility for the project, ending the former collaboration with an independent research team (Ousterhout et al 2009: 236). The restoration of the mosque continued under the new powers in charge, criticized by archaeologists and historians for the use of inadequate building material and alteration of the original façade. 


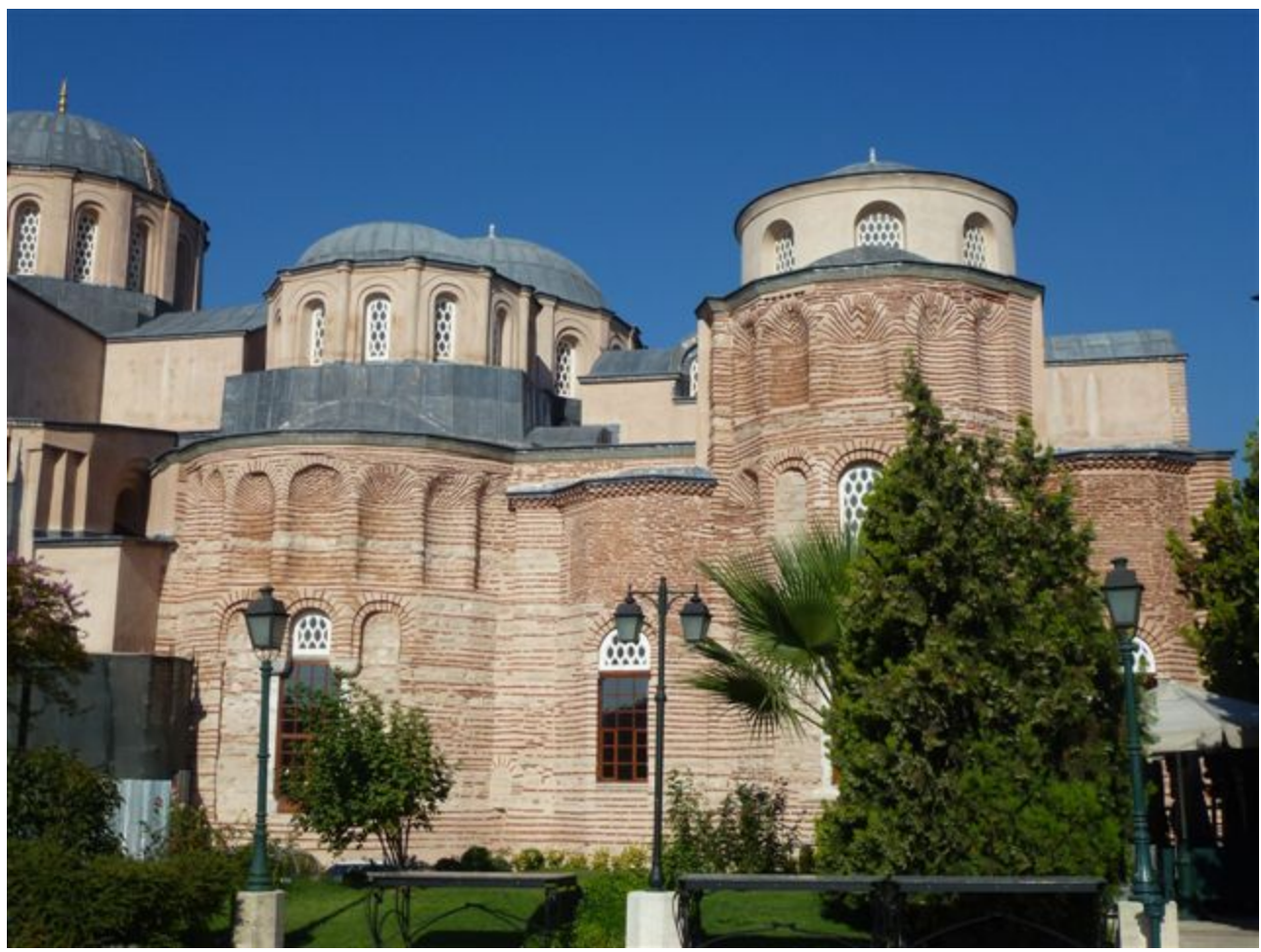

Zeyrek Mosque shortly after the completion of the exterior restoration works in September 2013 Marquart, 2013

Not only the mosque, but also the adjacent cistern and its surrounding area were restored. The buildings were often demolished or only the façades were restored, leaving the run down interior untouched..$^{19}$

Additionally, restoration projects mark the area along the land walls including the restoration of parts of the Byzantine Palace of Blachernae. Tourist promotions had long neglected this part of the city, stigmatizing it as a dangerous area. Now, several restoration projects in historic neighbourhoods, such as in Sulukule, indicate the newly attributed importance of such areas. ${ }^{20}$ The projects serve tourism, for example, through the construction of hotels and cafés, but they are also intended to change the socioeconomic environment of residents by creating gated communities for a more affluent middle class. Therefore, the shift in the promotion of heritage also has direct and farreaching effects on the lives of the residents in these areas.

Ayvansaray is one of these neighbourhoods adjacent to the Theodosian land walls and part of the WH area. The area around Toklu Ibrahim Dede Sokağ (Tokludede) is home to exceptional examples of vernacular architecture with 15 protected houses. In 2010, Fatih municipality designated the Ayvansaray as a Renewal Area with the aim of improving the environment through the restoration of its civil architecture (Fatih Belediyesi 2010), which would also mean the demolition of old houses and a complete renewal of the area. The implementation in Tokludede started in 2012. 


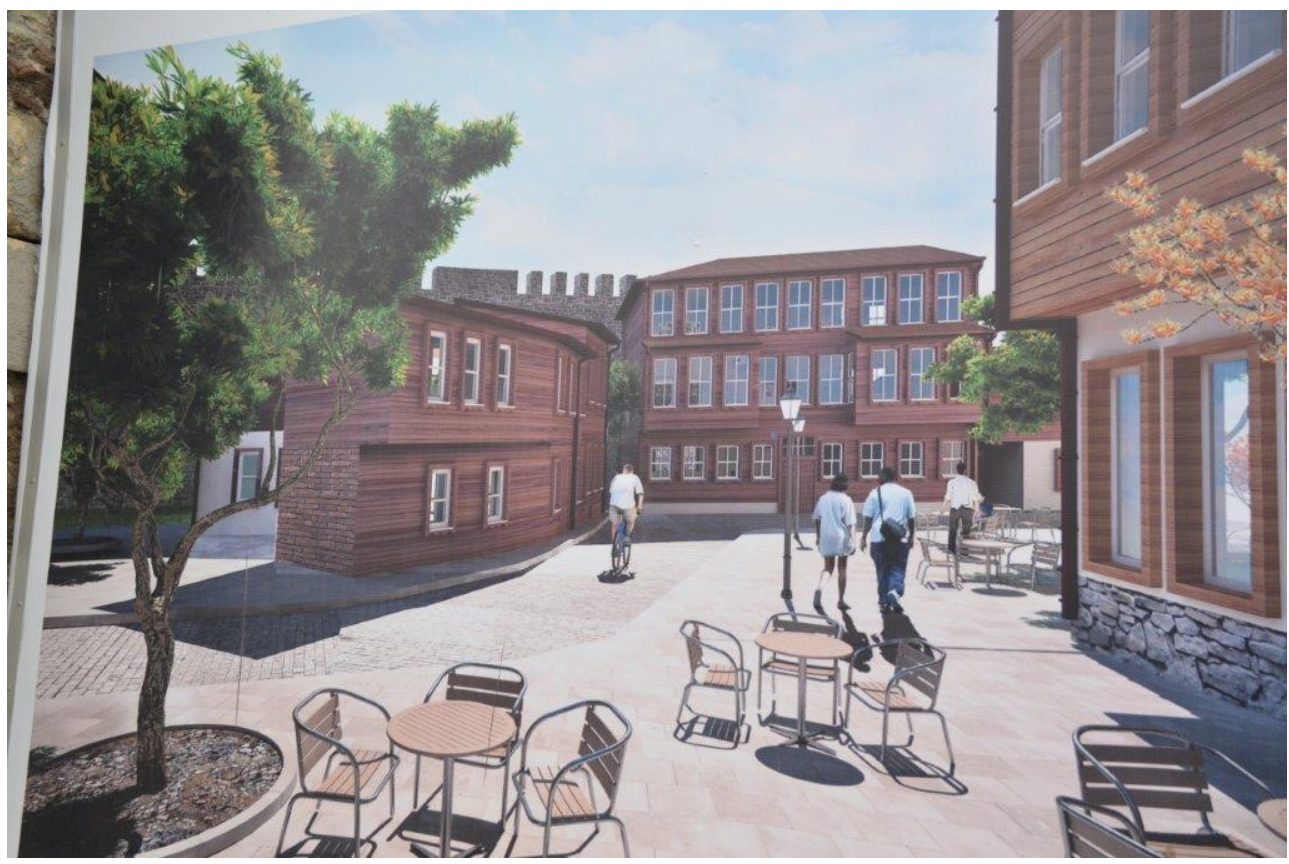

Hoardings in Tokludede neighbourhood promoting the transformation of the areas in front of the land walls

Marquart, 2013

Despite its status as a protected WH area, the realization of the project received little public attention with only a few objections raised by neighbourhood associations. Already by October 2012, visible changes had been made to the building structures of the Tokludede neighbourhood, with fences erected around the area. From spring 2013, access to the area was made increasingly difficult, with security patrolling the construction site. The project proceeded rapidly; by now the first buildings are scheduled to have been completed. Hoardings around the area are promoting replicas of historical wooden houses and clean, widened streets with cafés situated in front of the land walls.

Zeyrek Mosque and Ayvansaray neighbourhood are good examples of how heritage is being used for the promotion of tourism. In both cases, the history and the past were (re)negotiated through present day policies. Not only the historical features, but the purpose of the renovation -upgrading the areas to attract tourists-comes to the fore in both projects. Zeyrek Mosque was restored to attract tourists interested in Istanbul's Byzantine-Christian heritage, and after years of neglect the area along the land walls has been (re)discovered for its investment potential. In these cases, heritage preservation was not opposed to modern urban development, but it was rather (re)constructed to serve the latter's needs.

With regard to these examples, we are also able to examine the importance of the WH label and consider whether the transformation of WH areas differs from those in other historic neighbourhoods, whether the $\mathrm{WH}$ label helps to protect historic neighbourhoods, and whether it builds awareness among local stakeholders. To respond to these questions, and to make such a comparison, I will present the example of a non-WH area, Tarlabaşı neighbourhood, one of the most prominent urban renewal areas in Istanbul. The neighbourhood is adjacent to the central Taksim Square and Istiklal Street, the main pedestrian shopping street in Istanbul. The area is known for 
its particular form of historical building structures and the long-term residence of different minority groups (see also Pérouse 2009). A new tourism and commercial district was planned with the construction of new housing complexes. The scope of the project comprises a $20,000 \mathrm{~m}^{2}$ area and includes 278 building structures (Beyoğlu Belediyesi 2011). Local protest groups, e.g. Istanbul SOS Platform, and the (international) media have constantly drawn attention to dubious developments in the process of the project's realization, and a neighbourhood association has been actively engaged in fighting against the destruction of the old environment. ${ }^{21}$ The association filed court cases against the project and petitioned the municipality. These actions slowed down the implementation process for some time but ultimately did not prevent its realization (Schwegmann 2013: 238). The renewal of the area and the eviction of its residents started in 2012 and the project is currently due to be completed with the first buildings sold by the end of November 2013 .

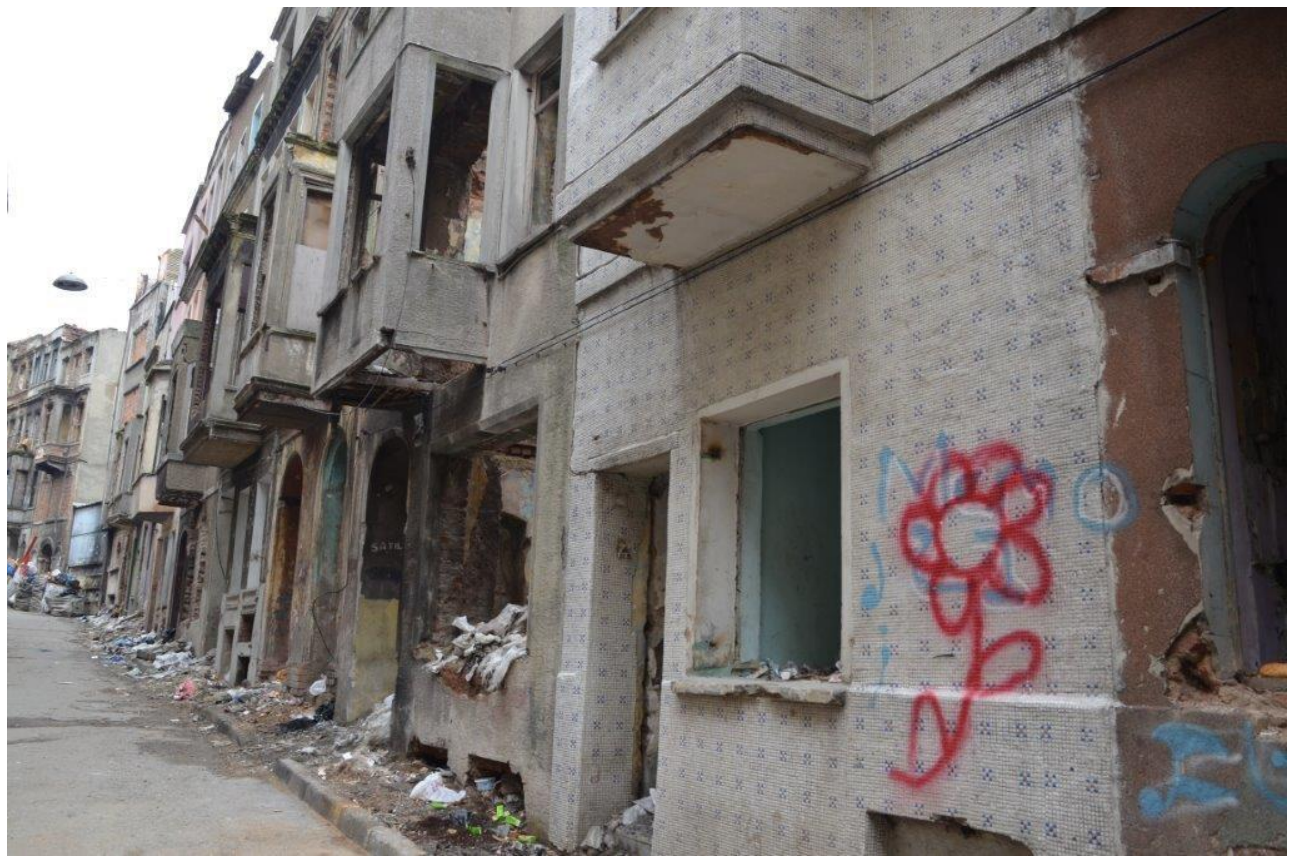

Abandoned houses within the area of the Tarlabașı transformation project

Marquart, 2013

Regarding implementation practice, there were no vast differences between the transformation projects in Ayvansaray and Tarlabaşı. Both project were planned either without residents' participation or public involvement. In fact, in both cases the public remained largely uninformed about the details until after implementation was underway. Nevertheless, the Tarlabaşı project gained much greater attention in public discourse than the transformation of the $\mathrm{WH}$ areas. Local and international media were constantly drawing attention to the demolition of historical building structures and the displacement of residents. Comparable to the Sulukule case, where the displacement of a Roma community and the demolition of the neighbourhood resulted in broad international protests in 2008, the marginalization of resident minorities was the main focus of the argument against the Tarlabaş1 project. Additionally, the location of the neighbourhood, being situated in close proximity to the central Taksim Square, might have been another reason for the stronger contestation of the transformation project. 
The perceptual importance given to the neighbourhood by residents and local activists contrasts with the official determination of WH areas, raising the question of the impact of the WH label. In Ayvansaray and Tarlabaşı historic buildings were demolished to make way for new constructions. The WH label did not hinder project implementation in Ayvansaray and local protests were retained. The reconstruction of Tarlabaşı, however, caused broad local resistance without being a WH area. Its status as home to different minority groups and its central location helped to perpetuate the protests against the transformation project.

The discrepancy between local perceptions of what constitutes important heritage and the official inscription of a WH site is crucial in the presented examples. In comparing the cases of Ayvansaray and Tarlabaşı, one can also see that the WH label provided little protection against intervention in an inscribed neighbourhood. In fact, Ayvansaray's status as a neighbourhood in a WH area had no adverse effects on the project's realization. Instead, it was strong local engagement in Tarlabaşı, which was responsible for delaying the project. The WH label also failed to empower local stakeholders in their protests against the transformation project. In Istanbul, the label was rather exclusively used by the local and national government for the promotion and attraction of investments.

7 However, UNESCO was not totally absent from local stakeholder discourses, and since 2009 the possible referral of Istanbul to the List of WH in Danger has been actively used to protest against the construction of the metro bridge over the Golden Horn. ${ }^{22}$ The recently opened bridge connects the metro line from şişhane to Yenikapı by crossing the Golden Horn, and then driving a tunnel under the Süleymaniye WH area. Since implementation started in 2009, various stakeholders have criticized the project. It was mostly the design of the steel cable bridge with its two high pylons and an additional stop in the middle of the bridge that caused dispute as to how the silhouette of the Historic Peninsula would be damaged by the project.

In July 2010, a group of professors and students from Mimar Sinan University established the Istanbul SOS Platform. The platform aimed to protect Istanbul's cultural heritage as a reaction to a possible inscription on the List of WH in Danger announced by the WHC. Mainly focusing on the bridge project at first, the platform went on to concentrate on other issues such as the implementation of Law No. 5366 in neighbourhoods like Tarlabaşı. Istanbul SOS Platform, supported by prominent Istanbulites such as Orhan Pamuk and Ara Güler, drew attention to inconsistencies in the realization process and proposed an alternative plan for the metro bridge (Vardar 2012).

In its annual decisions, the WHC also criticized the project for destroying the silhouette of Istanbul's Historic Peninsula and asked for the design to be modified (UNESCO 2009; UNESCO 2011). The media also widely discussed the issue (e.g. Altan 2013; Güneş 2012), presenting the planned bridge as a project that lacked public approval. In fact, although the public was largely uninformed about the project plans and its realization, many residents were nevertheless quite pleased with its outcome. With the process of the bridge construction and the renewal of Süleymaniye neighbourhood underway, businessmen -especially in Süleymaniye- saw the project as a chance to make the area more attractive for tourists. "Of course more tourists will come to the area with the new bridge. We are waiting for them!", explained Hüseyin, the owner of a café, while pointing in the direction of the Golden Horn. ${ }^{23} \mathrm{He}$ was hoping that the neighbourhood would be 
generally upgraded with a better transport connection to other parts of the city. Other Istanbulites also appreciated the improvements in the public transportation system, which would allow them to travel the city in much less time. "You know how long it takes to reach the other side", said businesswoman Meltem, "who would not be happy about this improvement?" ${ }_{24}$ Tourists from different countries especially emphasized the beautiful design of the bridge, hoping that the pylons would be illuminated the same way as the much bigger Bosporus Bridge.

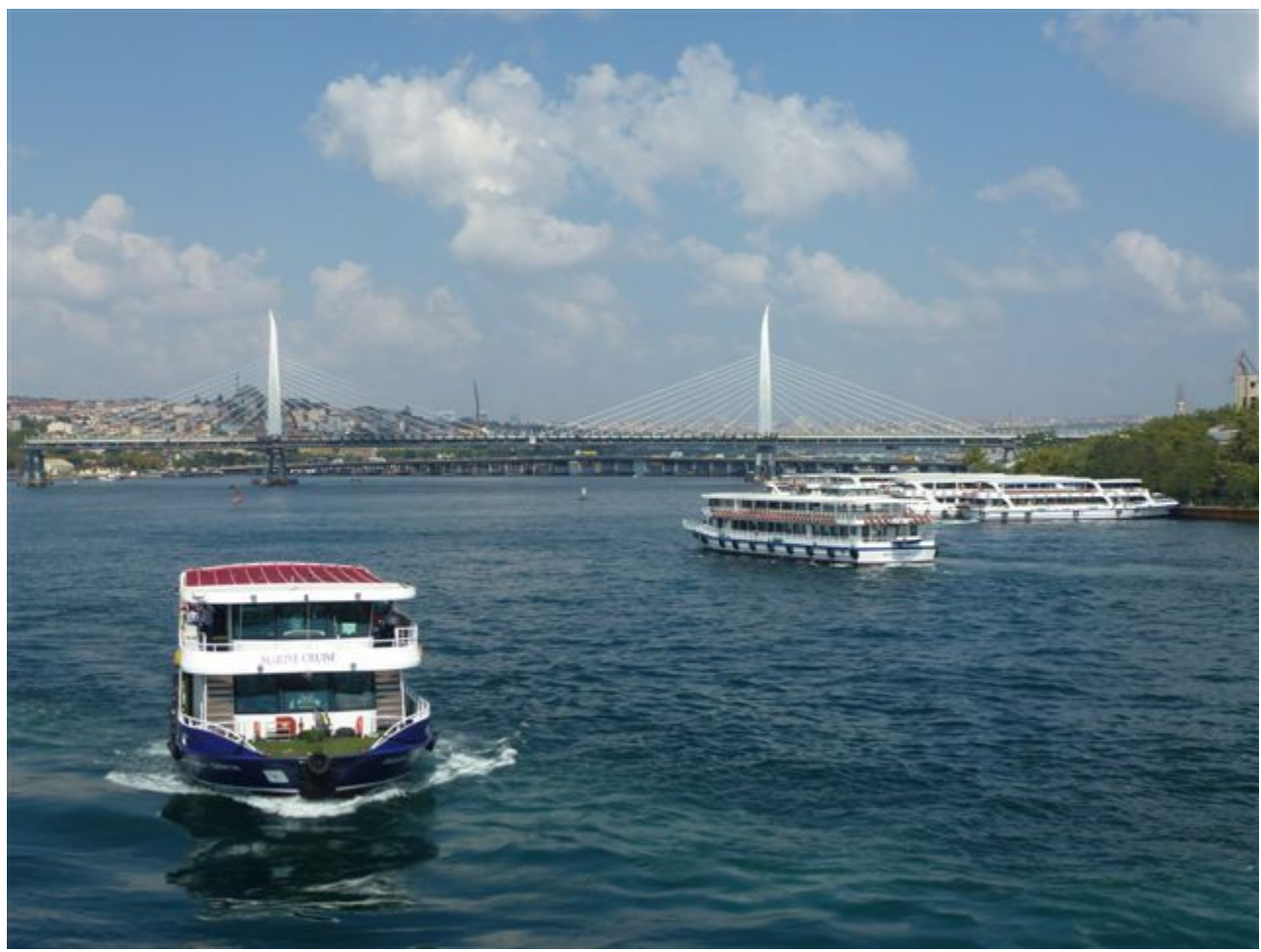

The Haliç Metro Bridge

Marquart, 2013

50 The protesters focused mainly on the question of the unclear division of responsibilities in the construction, design, and location of the metro bridge. As an infrastructural project lying within the boundaries of the city, the project falls under the jurisdiction and responsibility of the IMM, and yet the national government was widely involved in the promotion of the project. As WH areas were affected by the project, it was also the national government's responsibility to prepare reports for submission to the WHC. In his opening speech at a congress on heritage, held at Istanbul University in November 2011, the Fatih Municipality Mayor explicitly prioritized the improvement of the public transportation network over the preservation of heritage. He stressed that whilst heritage preservation was important, improvement in the living conditions of Fatih's residents was more so critical.

51 Rumours about the actual designer of the bridge were widely spread among opponents of the bridge. Members of the Chamber of Architects, and also people working at Conservation Councils and at the Turkish National Commission for UNESCO, were unsure about the quality of the information provided. Critics of the project were not only questioning the lines of action, but also discussing conscious misguidance in the implementation of the project (Karadeniz 2013). The official architect of the metro bridge, Hakan Kiran, had presumed that opponents to the project would spread false 
information to UNESCO and the public in order to hamper the realization of the project (Salcioğlu 2011). Given that mutual offenses were made on the part of protesters and officials and a there was a lack of transparency in the implementation process, suspicion characterized the discourse on its construction. Due to this ambiguity in the management of cultural heritage, debates were not so much about actual responsibilities and project facts, but more about the lack of transparency in the decision-making process.

In his article on legal ambiguity in the transformation of Istanbul's informal settlements, Kuyucu examines legal ambiguity as an important tool for the creation and institutionalization of Turkey's private property regime. He sees this ambiguity not only as a way to forcefully appropriate people's property, but also as a strategy for the prevention of the formation of an effective opposition against such projects. In situations wherein the contents of projects are not made fully available to the opposition, it becomes difficult to create a concrete argument and mobilize the public against its implementation (Kuyucu 2013: 16-17). In my opinion, this is also one of the strongest arguments for the successful implementation of favoured projects in heritage areas. Not only local stakeholders, but also people working in official institutions such as the Turkish National Commission for UNESCO and the Ministry of Culture and Tourism, felt this ambiguity. Holding important positions in different institutions and being partly involved in the decision-making process concerning the preservation of cultural heritage, these officials referred to an innominate decision-making power that, at any point, could overrule their authority. Beyza is a professor of urban planning and involved in the preparation of a strategy plan for the Historic Peninsula. One day she complained: "My name is on this report, but this doesn't mean that these are my ideas. You can put all your effort in this, but in the end it is not what you have written anymore." ${ }^{25}$ Others explained that they were excluded from committees for not adhering to the promoted opinion. Some informants tied these strategies directly to the Prime Minister, but mostly the explanations were more imprecise, and responsibility -without a clear distinction of what such responsibilities may actually entail- was attributed more vaguely to "the people in Ankara" or to "the Ministry".

53 As previously highlighted, UNESCO, as a transnational institution, is also unable to enforce alternatives to the transformation projects in WH areas. The WHC is a political arena for different States Parties and their diverse interests. For many nation states, the WH List is still a display of their national power (Atakuman 2010). By using its influence in the WHC, the Turkish government and its institutions can implement favoured projects, e.g. the metro bridge, without being at serious risk of losing WH status of Istanbul's sites (see also Meskell 2013). After years of heavily criticizing the metro bridge project, the WHC refrained from considering an inscription on the List of WH in Danger since its 2010 annual session.

Thus, the "Directors of Urban Change" (Nas 2005) retain control over the transformation of the city. The area along the land walls was transformed and the metro bridge was opened in February 2014. Many people, including those critical voices against current developments in heritage preservation, are involved in the management of heritage in different institutions and therefore kept busy with something considered to be close to their hearts. However, as they have neither decision-making powers nor a clear picture of how and by whom decisions are made, they are unable to create an alternative to the officially promoted projects. 


\section{Concluding Remarks}

The construction of heritage is a continuous process of socialization, interaction, and negotiation (Harrison 2004). This does not mean an equal exchange between political and local interests, but is more often a top down process. Thus, the "culture of reconstruction" inherent in Istanbul's transformation policy applies to the promotion and construction of cultural heritage and serves as a stimulator for investment in development projects. The Turkish national government is using the WH label to promote the $\mathrm{WH}$ areas' eligibility for tourism and investments in the housing sector. This is possibly due to UNESCO's limited power to intervene at the local level. Thus, the WH label proves to be insufficient for the protection of historic neighbourhoods, such as Zeyrek or Ayvansaray. That the UNESCO label is not acknowledged as a safeguard of heritage is also reflected in the local stakeholder's reaction towards the transformations of these areas. It is the historic neighbourhood of Tarlabaş that has attracted the majority of public attention compared to the WH area of Ayvansaray, where resistance was mobilized only on a smaller scale occurred during the realization of the transformation project. Tarlabaşı's status as a home for minorities and its central location seem to have been more decisive factors in the formation of local protest groups than Ayvansaray's WH status.

Its relative powerlessness and insignificance at the local level is contrasted by the WHC's importance as a political arena for different States Parties and their diverse interests. UNESCO's international requirements for heritage preservation have even help to establish a legal and executive framework and ensure involvement in an international heritage discourse, without the need of wider local involvement. Fulfilling the formal criteria in its heritage management, Turkey established a complex system of "centralized fragmentation" that pinpoints the aim of the national government to keep control over decentralized (and sometimes even privatized) institutions.

7 The range of different institutions involved in heritage preservation signifies formal effectiveness, but it also creates ambiguity about actual responsibilities. These ambiguities -the lack of knowledge about responsibilities, the planning process, and the interpretation of legal regulations- allow favoured urban transformation projects to be realized in historic neighbourhoods. Likewise, it hinders the rise of a potent opposition that could challenge these projects. Professionals and critics are included in the perpetuation of this elaborate management system through the preparation of strategy plans or participation in conservation councils. Thus, these stakeholders are faced with the dilemma of being involved in (and partly dependent on) a system that they do not believe in.

Aside from top-down decisions, the ambiguities in the management system are an effective tool for the integration of opponents into a system they dislike, but are ultimately dependent on. In this regard, political ambiguity may be considered not as a structural deficit, but rather as a successful strategy that offers enough flexibility to combine heritage management with political priorities, such as urban transformation. 


\section{BIBLIOGRAPHY}

Askew, Marc (2010) “The Magic List of Global Status: Unesco, World Heritage and the Agendas of States", in Labadi, Sophia; Long, Colin (eds.), Heritage and Globalisation, London, Routledge, pp. 19-44.

Atakuman, Çiğdem (2010) "Value of Heritage in Turkey: History and Politics of Turkey’s World Heritage Nominations”, Journal of Mediterranean Archaeology 23 (1), pp. 107-31 URL: http:// www.equinoxpub.com/journals/index.php/JMA/article/view/9220

Bartu, Ayfer (2001) "Rethinking Heritage Politics in a Global Contexts. A View from Istanbul”, in AlSayyad, Nezar (ed.), Hybrid Urbanism, London: Praeger, pp. 131-155.

Bayraktar, Ulaş; Massicard, Élise (2012) “Decentralisation in Turkey”, Focales 7, URL: http:// www.afd.fr/webdav/shared/PUBLICATIONS/RECHERCHE/Scientifiques/Focales/07-VAFocales.pdf (retr. 28.07.2014).

Berliner, David (2012) “The Politics of Nostalgia and Loss in Luang Prabang (Lao PDR)”, in Daly, Patrick; Winter, Tim (eds.), Routledge Handbook of Heritage in Asia, Oxon/New York, Routledge: pp. 234-246.

Bezmez, Dikmen (2008) "The Politics of Urban Waterfront Regeneration: The Case of Haliç (The Golden Horn), Istanbul”, International Journal of Urban and Regional Research 32(4): pp. 815-840. URI: http://dx.doi.org/10.1111/j.1468-2427.2008.00825.x/

Bilsel, Cânâ (2011) “'Les Transformations d'Istanbul': Henri Prost's Planning of Istanbul (1936-1951)”, ITÜ AZ 8(1): pp. 100-116.

Black, Heather; Wall, Geoffrey (2001) “Global-Local Inter-Relationships in UNESCO World Heritage Sites”, in Teo, Peggy (ed.), Interconnected Worlds. Tourism in Southeast Asia, Amsterdam, Pergamon: pp. 121-136.

Bonini Baraldi, Sara; Shoup, Daniel; Zan, Luca (2012) “Understanding Cultural Heritage in Turkey: Institutional Context and Organizational Issue”, International Journal of Heritage Studies 19 (7), pp. 728-748. URI: http://dx.doi.org/10.1080/13527258.2012.700283

Bonini Baraldi, Sara; Shoup, Daniel; Zan, Luca (2014) “A Centralized Decentralization: Outsourcing in the Turkish Cultural Heritage Sector", International Journal of Cultural Policy 1(1): pp. 54-77. URI: http://dx.doi.org/10.1080/10286632.2012.731051

Brumann, Christoph. (2011) "Unser Aller Kulturgut: Eine Ethnologische Annäherung an Das Unesco-Welterbe”, Sociologus 61, pp. 19-44. URI: http://dx.doi.org/10.3790/soc.61.1.19

Brumann, Christoph (2012) "Multilateral Ethnography: Entering the World Heritage Arena", Max Planck Institute for Social Anthropology Working Papers 136. URL: http://www.eth.mpg.de/ download.php?f=mpi-eth-working-paper-0136.pdf

Cameron, Christina; Rössler, Mechtild (2013) Many Voices, One Vision: The Early Years of the World Heritage Convention, Farnham: Ashgate.

Deniz, Yusuf; Çalışkan, Ahmet Ziya (2014), “Organization of Local Administration in Turkey”, The Macrotheme Review 3 (4): pp. 102-06. URL: http://macrotheme.com/yahoo_site_admin/assets/ docs/13MR31DTu.1365317.pdf

Dinçer, Ical; Enlil, Zeynep; Islam, Tolga (2008) "Regeneration in a New Context: A New Act on Renewal and Its Implications on the Planning Processes in Istanbul”, paper presented at Bridging 
the Divide: Celebrating the City. ACSP- AESOP Fourth Joint Congress, Chicago. URL: https:// reclaimistanbul.files.wordpress.com/2011/04/aesop_080602_dincer-enlil-islam-renewal_law.pdf Eldem, Edhem (2012) “Osmanlı İpiyle Kuyuya İnmek”, Altüst 8, URL: http://www.altust.org/ 2013/02/osmanli-ipiyle-kuyuya-inmek/

Frey, Bruno S. (2013) “World Heritage List”, in Rizzo, Ilde (ed.), Handbook on the Economics of Cultural Heritage, Cheltenham: Elgar, pp. 171-186.

Fuhrmann, Malte (2013) “Istanbul's Pasts: Raw Material for Construction the City's Future”, in Ginio, Eyal; Kaser, Karl (eds.), Ottoman Legacies in the Contemporary Mediterranean. The Balkans and the Middle East Compared, Jerusalem, The European Forum at the Hebrew University: pp. 255-285. URL: http://www.ef.huji.ac.il/publications/Ottoman\%20Legacies/

Malte\%20Fuhrmann_Istanbuls\%20Pasts.pdf

Girard, Muriel; Scalbert-Yücel, Clémence (2014) « Le patrimoine comme catégorie d'action publique dans la région du sud-est anatolien », in Aymes, Marc; Gourisse, Benjamin; Massicard, Elise (eds.), L'Art de l'État. Arrangements de l'Action Publique en Turquie, de la Fin de l'Empire Ottoman à nos Jours, Paris, Karthala, pp. 195-221.

Günay, Zeynep; Dökmeci, Vedia (2012) “Culture-Led Regeneration of Istanbul Waterfront: Golden Horn Cultural Valley Project”, Cities 29, pp. 213-22. URI: http://dx.doi.org/10.1016/j.cities. 2011.08.010

Harrison, David (2004) "Introduction: Contested Narratives in the Domain of World Heritage", Current Issues in Tourism 7 (4/5), pp. 281-90. URI: http://dx.doi.org/10.1080/13683500408667985

Herzfeld, Michael (1991) A Place in History-Social and Monumental Time in a Cretan Town, Princeton, Princeton University Press.

Herzfeld, Michael (2006) "Spatial Cleansing- Monumental Vacuity and the Idea of the West", Journal of Material Culture 11 (1/2), pp. 127-49. URI: http://dx.doi.org/10.1177/1359183506063016 Hoggart, Richard (2011) An Idea and Its Servants: UNESCO From Within, New Brunswick: Transaction Publishers.

Isar, Yudhishthir Raj (2011) "UNESCO and Heritage: Global Doctrine, Global Practice”, in Anheier, Helmut and Isar, Yudhishthir Raj (eds.), Heritage, Memory \& Identity, Los Angeles: Sage, pp. 39-52. URI: http://dx.doi.org/10.4135/9781446250839

Joy, Charlotte (2012) The Politics of Heritage Management in Mali. From UNESCO to Djenné, Walnut Creek, Left Coast Press.

Karaman, Ozan; Islam, Tolga (2012) "On the Dual Nature of Intra-Urban Borders: The Case of a Romani Neighborhood in Istanbul”, Cities 29, pp. 234-243. URI : http://dx.doi.org/10.1016/j.cities. 2011.09.007

Kocabaş, Arzu. (2006) "Urban Conservation in Istanbul: Evaluation and Re-Conceptualisation", Habitat International 30: pp. 107-126. URI: http://dx.doi.org/10.1016/j.habitatint.2004.08.001

Kuban, Doğan (1996) Istanbul An Urban History, Istanbul: The Economic and Social History Foundation of Turkey.

Kurtuluş, Hatice (2009) “Kentsel Dönüșümün Politik Ekonomisi”, İktisat Dergisi 499, pp. 26-33. 
Kuyucu, Tuna; Ünsal, Özlem (2010) “Urban Transformation as State-led Property Transfer: An Analyses of two Cases of Urban Renewal in Istanbul", Urban Studies 47: pp. 1479-1498. URI: http:// dx.doi.org/10.1177/0042098009353629

Kuyucu, Tuna (2013) "Law, Property, and Ambiguity: The Uses and Abuses of Legal Ambiguity in Remaking Istanbul's Informal Settlements", International Journal of Urban and Regional Research, doi:10.1111/1468-2427.12026. URI: http://dx.doi.org/10.1111/1468-2427.12026

Labadi, Sophia; Long, Colin (2010) “Introduction”, in Labadi, Sophia; Long, Colin (eds.), Heritage and Globalisation, London, Routledge, pp. 1-16.

Meskell, Lynn (2013) “Unesco's World Heritage Convention at 40: Challenging the Economic and Political Order of International Heritage Conservation", Current Anthropology 54 (4), pp. 483-94. URI: http://dx.doi.org/10.1086/671136

Nas, Peter J. M. (2005) “Introduction. Directors of Urban Change”, in Nas, Peter J.M. (ed.), Directors of Urban Change in Asia, London and New York, Routledge, pp.1-13.

Nielsen, Bjarke (2011) "UNESCO and the 'Right' Kind of Culture: Bureaucratic Production and Articulation", Critique of Anthropology 31(4), pp. 273-292. URI: http://dx.doi.org/ 10.1177/0308275X11420113

Öncü, Ayşe (2007) “The Politics of Istanbul's Ottoman Heritage in the Era of Globalism. Refractions through the Prism of a Theme Park", in Drieskens, Barbara; Mermier, Franck; Wimmen, Heiko (eds.), Cities of the South: Citizenship and Exclusion in the 21st Century, London, Saqi/ Heinrich Böll Fondation, pp. 233-64. URL: http://research.sabanciuniv.edu/9395/

Öncü, Ayşe (2010) “Narratives of Istanbul's Ottoman Heritage”, in Diamandouros, P. Nikiforos; Dragonas, Thalia; Keyder, Çağlar, Spatial Conceptions of the Nation- Modernizing Geographies in Greece in Turkey, London, New York:Tauris Academic Studies, pp. 205-228.

Ousterhout, Robert; Ahunbay, Metin; Ahunbay, Zeynep (2009) "Study and Restoration of the Zeyrek Camii in Istanbul: Second Report 2001-2005”, Dumbarton Oaks Papers 63, pp. 236-56. URL: http://www.jstor.org/stable/41219768

Pérouse, Jean-François (2009) « Émergence et Résorption Annoncées d'un Territoire de Transit International au Cœur d'Istanbul: Le Cas de Tarlabaş1 (1987-2007) », Maghreb - Machrek No. 199, pp. 85-101. URI: http://dx.doi.org/10.3917/machr.199.0085

Pérouse, Jean-François (2010) « Cinq raisons d'un éventuel déclassement UNESCO », Urbanisme No. 374: p. 66.

Pérouse, Jean-François (2013) "Hybristanbul, les grands projets d'aménagement urbain en Turquie", La vie des idées (24.09.2013), URL: http://www.laviedesidees.fr/Hybristanbul

Pinon, Pierre (2010) « Henri Prost et le plan directeur d'Istanbul: Une œuvre inachevée », Urbanisme No. 374: pp. 52-55.

Potuoğlu-Cook, Öykü (2011) "Summer of Shame. Displaced Roma in Istanbul, Turkey", Anthropology News, March 2011, p. 15. URI: http://dx.doi.org/10.1111/j.1556-3502.2011.52315.x

Saraçoğlu, Cenk; Demirtaş-Milz, Neslihan (2014) "Disasters as an Idealogical Strategy for Governing Neoliberal Urban Transformation in Turkey: Insights from Izmir/ Kadifekale", Disasters 38(1), pp. 178-201. URI: http://dx.doi.org/10.1111/disa.12038

Schwegmann, Martin (2013) Istanbul and the Grassroots. Civil Society Organisations, Local Politics and Urban Transformation, Berlin: Technische Universität Berlin. URL: opus4.kobv.de/opus4-tuberlin/ files/3695/schwegmann_martin.pdf 
Şeni, Nora (2010) «La tentative néo-ottomane et la rénovation du quartier de la Süleymaniye », Urbanisme No. 374: pp. 41-42.

Shoup, Daniel; Zan, Luca (2013) “Byzantine Planning: Site Management in Istanbul”, Conservation and Management of Archaeological Sites 15(2): pp. 169-194. URI: http://dx.doi.org/

$10.1179 / 1350503313 Z .00000000054$

Somuncu, Mehmet; Yiğit, Turgut (2010) “World Heritage Sites in Turkey. Current Status and Problems of Conservation and Management”, Coğrafi Bilimler Dergisi 8(1), pp. 1-26. URL: http:// dergiler.ankara.edu.tr/dergiler/33/1339/15512.pdf

Şahin Güçhan, Neriman; Kurul, Esra (2009) “A History of the Development of Conservation Measures in Turkey: From the Mid 19th Century until 2004", METU JFA 26(2), pp. 19-44. URI: http://dx.doi.org/10.4305/METU.JFA.2009.2.2

Şen, Besime (2009) “Kentsel Dönüşüm: Kavramsal Karmaşa ve Neoliberalizm”, İktisat Dergisi No. 499, pp. 34-41. URL: http://www.academia.edu/1106903/

Kentsel_D\%C3\%B6n\%C3\%BC\%C5\%9F\%C3\%BCm_Kavramsal_Karma\%C5\%9Fa_ve_Neoliberalizm

Uysal, Ülke Evrim (2012) “An Urban Social Movement Challenging Urban Regeneration: The Case of Sulukule, Istanbul”, Cities 29, pp. 12-22. URI: http://dx.doi.org/10.1016/j.cities.2011.06.004

Y1lmaz, Evrim (2012) "Urban Transformation Policies and the Irrepressible Rise of TOKí, Perspectives - Political Analysis and Commentary from Turkey 3: pp. 40-43. URL: http:// www.academia.edu/2469717/

Urban_Transformation_Policies_and_the_Irrepressible_Rise_of_TOK\%C4\%B0

\section{Newspaper articles}

Altan, Barış (2013) “Başka bir köprü mümkündü!”, Radikal 2 (27.10.2013), URL: http:// www.radikal.com.tr/radikal2/baska_bir_kopru_mumkundu-1157312\# (retrieved 29.01.2014).

Çektir, Berk (2012) “The New Law Creating More Metropolitan Municipalities”, Today's Zaman (18.12.2012), URL: http://www.todayszaman.com/columnists/berk-cektir_301531-the-new-lawcreating-more-metropolitan-municipalities.html (retrieved 29.01.2014).

Güneş, Erdem (2012) “Haliç Bridge shaping up”, Hürriyet Daily News (17.09.2012), URL:

http://www.hurriyetdailynews.com/halic-bridge-shaping-up.aspx?pageID=238\&nid=30282 (retrieved 29.01.2014).

Hülağü, Ayhan (2011) “New Buildings Pose Threat to Istanbul's Historic Silhouette”, Today's Zaman (11.09.2011), URL: http://www.todayszaman.com/newsDetail_getNewsById.action? newsId=256346 (retrieved 29.01.2014).

Karadeniz, Barış (2013) “Controversy as Golden Horn Metro Bridge nears Completion”, Demotix (03.03.2013), URL: http://www.demotix.com/news/1843893/controversy-golden-horn-metrobridge-nears-completion\#media-1843770 (retrieved 29.01.2014).

Salcıoğlu, M. (2011) "UNESCO Science Committee Approves Construction of Haliç Metro Bridge”, Today's Zaman (08.05.2011), URL: http://www.todayszaman.com/news-243242-unesco-sciencecommittee-approves-construction-of-halic-metro-bridge.html (retrieved 29.01.2014).

Vardar, Nilay (2012) “Haliç’e Başka Bir Köprü Mümkün”, Bianet (06.03.2012), URL: http:// bianet.org/bianet/toplum/136711-halic-e-baska-bir-kopru-mumkun (retrieved 29.01.2014). 


\section{Official documents}

UNESCO (2003) Decisions adopted by the World Heritage Committee at its 27th Session, Doc. WHC-03/27.COM/24, Paris: UNESCO.

UNESCO (2006a) Decisions adopted by the World Heritage Committee at its 30th Session, Doc. WHC-06/30.COM/19, Paris: UNESCO.

UNESCO (2006b) World Heritage Centre and ICOMOS Joint Reactive Monitoring Mission Report, Historic Areas of Istanbul, 06-11 April 2006, Paris: UNESCO.

UNESCO (2009) Decisions adopted by the World Heritage Committee at its 33th Session, Doc. WHC-09/33.COM/20, Paris: UNESCO.

UNESCO (2011) Decisions adopted by the World Heritage Committee at its 34th Session, Doc. WHC-11/35.COM/20, Paris: UNESCO.

UNESCO (2012) World Heritage Centre and ICOMOS Joint Reactive Monitoring Mission Report, Historic Areas of Istanbul, 19-23 November 2012, Paris: UNESCO.

\section{Municipality websites}

Beyoğlu Belediyesi (2011) Tarlabaşı Renovation Project, URL: http://en.beyoglu.bel.tr/beyoglu/ services.aspx?SectionId=2079 (retrieved 29.01.2014).

Fatih Belediyesi (2010) Ayvansaray Yenileme Alanı, URL: http://www.fatih.bel.tr/icerik/7642/ ayvansaray-yenileme-alani/ (retrieved 29.01.2014).

\section{NOTES}

1. The PhD project is part of the research group 'The Global Political Economy of Cultural Heritage' at the Max Planck Institute for Social Anthropology in Halle (Saale), Germany.

2. For a more accurate description of the WH arena, see Brumann (2011). A more general overview of the WH Convention, the WH List and the works of UNESCO are presented in Frey (2013); Cameron and Rössler (2013); Brumann (2012); Hoggart (2011); Isar (2011); and Nielsen (2011).

3. Additionally, Turkey ratified the "Convention for the Protection of the Architectural Heritage of Europe" (1985), the "European Convention on the Protection of the Archaeological Heritage" (rev., 1992), and the "European Landscape Convention" (2000) (see UNESCO 2012).

4. The law corresponds in large parts to the terminologies used in the UNESCO Convention and was enacted in July 1983, only four months after the ratification of the UNESCO document. It was amended by Law No. 3386 (1987) and Law No. 5226 (2004). The latter law to this present day has remained the principle legislation governing the conservation of heritage.

5. Istanbul Metropolitan Municipality (IMM) is one of, at present, 30 metropolitan municipalities and it currently consists of 39 district municipalities. Istanbul Province, one of the country's 81 provinces, has the same boundaries as IMM. Therefore, the Istanbul Province governor and IMM mayor share their responsibilities in the same territory.

6. The Ministry of Culture and Tourism was established with Law No. 4848 in 2003. It replaced the former Ministry of Culture, established in 1989 (şahin Güçhan and Kurul 2009). 
7. As this article focuses on cultural heritage only, the preservation of natural heritage will not be discussed here in detail. In general, the Ministry of Environment and Urban Planning [Çevre ve şehircilik Bakanlığı] is responsible for the management of natural heritage sites.

8. For a more detailed description of the management system for cultural heritage in Turkey, see Bonini Baraldi et al. (2012).

9. A series of legal regulations stimulated further decentralization in the early 2000s. In 2005, the "Municipality Law" [Belediye Kanunu, Law No. 5393] assigned local administration with the implementation of urban transformation and development projects.

10. For a detailed analysis of this discrepancy between formal adoption of UNESCO requirements and the actual implementation in the case of Istanbul's Site Management Plan see Shoup and Zan (2013).

11. The idea of an "Archaeological Park" at the tip of the Historic Peninsula, as an open air museum, was brought up by Henri Prost during his time as city planner for Istanbul between 1936 and 1951. Until today this name is used in tourist promotions by the IMM as well as in the official inscription documents of UNESCO to describe the area at the tip of the historic peninsula. For more information on Henri Prost's master plan for Istanbul, see Bilsel (2011); and Pinon (2010).

12. To be included on the World Heritage List, sites must be of outstanding universal value (OUV) and fulfil at least one out of ten selection criteria. A site has to (i) represent a masterpiece of human creative genius; (ii) exhibit an important interchange of human values; (iii) bear a unique or at least exceptional testimony to a cultural tradition or to a civilization; (iv) be an outstanding example of a type of building, architectural or technological ensemble or landscape which illustrates (a) significant stage(s) in human history; (v) be an outstanding example of a traditional human settlement, land-use, or sea-use, (vi) be directly or tangibly associated with events or living traditions, with ideas, or with beliefs, with artistic and literary works of outstanding universal significance; (vii) to contain superlative natural phenomena or areas of exceptional natural beauty and aesthetic importance; (viii) to be outstanding examples representing major stages of earth's history, including the record of life, significant on-going geological processes in the development of landforms, or significant geomorphic or physiographic features; (ix) to be outstanding examples representing significant on-going ecological and biological processes in the evolution and development of terrestrial, fresh water, coastal and marine ecosystems and communities of plants and animals; (x) to contain the most important and significant natural habitats for in-situ conservation of biological diversity, including those containing threatened species of outstanding universal value from the point of view of science or conservation. Istanbul was inscribed on the base of selection criteria i, ii, iii, and iv (see URL: http://whc.unesco.org/en/ criteria/).

13. For a discussion on heritage recognition and public action in the South-East Anatolian cities of Mardin, şanlıurfa, and Diyarbakır see Girard and Scalbert-Yücel (2014).

14. Bizim Avrupa is connected to and orientates itself with Europa Nostra, an international organization focusing on the safeguarding of heritage committed to Western conservation principles. However, Bizim Avrupa is not a national branch of the international organization but was set up independently for formal reasons. Members of the association even complained about activities of Europa Nostra with the General Directorate of Pious Foundations that would conflict with the national association's interest.

15. On the UNESCO webpage it reads: "Reactive monitoring is foreseen in the procedures for the eventual deletion of properties from the World Heritage List as set out in paragraphs 48-56 of the Operational Guidelines. It is also foreseen in reference to properties inscribed, or to be inscribed, on the List of World Heritage in Danger as set out in paragraphs 86-93." (URL: http:// whc.unesco.org/en/173/, accessed. 18.07.2014).

16. Interview, 15.08.2013. 
17. At the moment 46 sites are inscribed on the List of World Heritage in Danger. The two deleted sites are the Arabian Oryx Sanctuary in Oman and the Dresden Elbe Valley.

18. The now annually celebrated Tulip Festival refers to the Ottoman Tulip Era [LÂle Devri]. The period from 1718-1730, taking its name from the extensive cultivation of tulips in the gardens, is politically recognized as a period of intellectual upturn with new trends in arts and science (Kuban 1996: 336). Since 2006 IMM celebrates the coming of spring with a several week-long festival in April. All over in parks and open spaces, millions of tulips are planted and an official festival program commemorates the Tulip Period with its prosperous art and architecture (see URL: http://www.ibb.gov.tr/sites/istanbuldalalezamani/Pages/AnaSayfa.aspx).

19. This is similar to the $\mathrm{WH}$ area of Süleymaniye. For more details on the renewal in Süleymaniye, see şeni (2010).

20. Sulukule (Neslişah ve Hatice Sultan Mahalleleri) was an old Roma quarter adjacent to the Theodosian land walls and part of Istanbul's World Heritage. The neighbourhood was demolished and its residents displaced in 2009 to make way for the construction of new buildings. Often referred to as a precedent in terms of local protest against an urban transformation project, its demolition caused broad national and international attention. For more detailed information on the project and the social movements against its realization, for example Potuoğlu-Cook (2011); Karaman and Islam (2012); and Uysal (2012).

21. The Tarlabaşı Property Owners and Tenant Aid and Social Developments Association [Tarlabaşı Mülk Sahipleri ve Kiracıları Kalkındırma ve Sosyal Yardımlaşma Derneği] was founded in February 2008.

22. For a more precise description of the WHC's reasons for discussing an inscription on the List of WH in Danger, see Pérouse (2010). The academic focus on Istanbul's WH status since 2009 does not reflect the urgency expressed by the WHC, as the latter repeated the consideration of Istanbul's referral since 2003. The 2009 attentiveness rather mirrors the importance that a possible inscription gained in the public discourse at that time.

23. Interview, 25.02.2013.

24. Interview, 27.10.2012.

25. Interview, 27.07.2013.

\section{ABSTRACTS}

This article gives an overview of the heritage management system in Turkey with a special focus on Istanbul. Referring to relevant works on this subject from the past few years, I want to illustrate the powerful role of the Turkish state and other important actors in the transformation of cultural heritage areas. Through a discussion of examples drawn from my own research in Istanbul, I review the label of UNESCO World Heritage and its potential to protect cultural heritage from inappropriate interventions and developments. The World Heritage Committee and people working in the field of heritage preservation often highlight structural deficits in the Turkish management system. Instead, I argue that seemingly inadequate conservation practices can also be interpreted as an integral part of the management system which allows for a combination of heritage preservation and urban transformation. A multi-faceted management structure pleases international organizations and investors, while ambiguous responsibilities 
hinder the formation of an effective opposition against urban transformation projects in historic neighbourhoods.

INDEX

Keywords: UNESCO World Heritage, urban transformation, heritage management, Istanbul, historic neighbourhoods

\section{AUTHOR}

\section{VIVIENNE MARQUART}

Max Planck Institute for Social Anthropology, Halle/Saale (Germany) 